\title{
Bireticulol, a bioactive isocoumarin dimer from Streptomyces sp. BCC24731
}

\author{
Chollaratt Boonlarppradab, Chanwit Suriyachadkun, Sumalee Suphothina and Punsa Tobwor
}

A new dimeric isocoumarin, bireticulol, was isolated from the terrestrial Streptomyces sp. and characterized as a 5-5' dimer of reticulol. In addition, reticulol and 8-hydroxy-6,7-dimethoxy-3-methyl isocoumarin, together with other known polyketides piericidin A, 2'-(2-hydroxyphenyl)-2,4'-bibenzoxazole-4-carboxylic acid methyl ester (UK-1) and 3-benzyl-4-hydroxy-5-methyldihydrofuran-2-one were also obtained. Bireticulol exhibited cytotoxic effects against KB (human epidermoid carcinoma, ATCC CCL-17) and NCI-H187 (human small cell lung cancer, ATCC CRL-5804) cell lines with $\mathrm{IC}_{50}$ values of 24.4 and $8.31 \mu \mathrm{g} \mathrm{ml}^{-1}$, respectively.

The Journal of Antibiotics (2011) 64, 267-270; doi:10.1038/ja.2010.171; published online 12 January 2011

Keywords: actinomycete; biisocoumarin; cancer cell cytotoxicity; natural product; oxidative coupling; Streptomyces sp

\section{INTRODUCTION}

Isocoumarins belong to an important class of secondary metabolites that display a diverse biological activities ${ }^{1}$ such as antifungal, ${ }^{2}$ antimicrobial, ${ }^{3}$ antitumor, ${ }^{4}$ anti-inflammatory, ${ }^{5}$ antiallergic, ${ }^{6}$ antimalarial ${ }^{7}$ and antioxidant ${ }^{8}$ effects. A wide range of isocoumarins have been obtained from various natural sources because of their remarkable bioactivities continue to attract and stimulate interest in many research areas. Although a significant number of isocoumarins have been isolated, there seemed to be not many reports regarding the dimeric form of naturally occurring isocoumarins. Few of those included the biisocoumarin, castanaguyone ${ }^{9}$ and the antifungal metabolite tithoniamarin. ${ }^{10}$ As part of the program to explore actinomycetes from Thailand that exhibit distinct biological activities, Streptomyces sp. BCC24731 was selected for further investigation. The initial screening indicated that BCC24731 was effective in malarial inhibition assay against Plasmodium falciparum K1 strain with moderate cytotoxicity against MCF7. Using bioassay guided-fractionation, a new dimeric isocoumarin, bireticulol (1), has been isolated in addition to its monomer counterpart, reticulol (2) (see ref. 11), and the closely related derivative, 8-hydroxy-6,7-dimethoxy-3-methyl isocoumarin (3) (see refs 12,13). Other several known polyketides were also derived from this strain including piericidin A (4) (see refs 14,15), UK-1 (5) (see refs 16,17) and 3-benzyl-4-hydroxy-5-methyldihydrofuran-2one (6) (see refs 18,19). This paper describes the fermentation, isolation, structural elucidation and semi-synthesis of 1 together with the biological activities of these compounds (Figure 1).

\section{RESULTS AND DISCUSSION}

Structure elucidation of $\mathbf{1}$, isolated as a yellow amorphous powder, was based on ESI-TOF HRMS and NMR data (Table 1). The molecular formula of bireticulol was determined by HRESIMS $\left([\mathrm{M}+\mathrm{Na}]^{+}=m / z\right.$ 465.0803) as $\mathrm{C}_{22} \mathrm{H}_{18} \mathrm{O}_{10}$. Analysis of the IR spectroscopic data showed a strong absorption band at $3449 \mathrm{~cm}^{-1}$ of hydroxyl group. In addition, the absorptions at 1679,1640 and $1467 \mathrm{~cm}^{-1}$ supported the presence of carbonyl functionalities and aromatic ring system.

The ${ }^{1}$ HNMR spectrum of $\mathbf{1}$, measured in acetone- $d_{6}$ (Table 1 ), illustrated four singlet proton signals, olefinic proton signal at $\delta 5.92$, methyl signal at $\delta 2.13$, methoxy group at $\delta 3.91$ and hydroxy proton signal at $\delta$ 11.56. The ${ }^{13} \mathrm{C}$ NMR/DEPT spectrum of 1 indicated the presence of a methyl group ( $\delta 18.3)$, a methoxy carbon $(\delta 60.0)$, an $\alpha, \beta$-unsaturated lactone/ester carbonyl $(\delta 166.8)$, four oxygenated olefinic/aromatic carbons $(\delta 153.4,156.8,133.6$, and $\delta 154.5)$ and four non-oxygenated olefinic/aromatic carbons $(\delta 102.2,134.3,107.3$, and $\delta 99.4)$. According to the number of signals from ${ }^{1} \mathrm{H}$ and ${ }^{13} \mathrm{C}$ NMR spectra, which were only half of that expected from the molecular formula, it could be deduced that this compound possesses a symmetrical dimer skeleton.

Positions of substituted functional groups in $\mathbf{1}$ were assigned by analysis of COSY and HMBC NMR spectral data (Figure 2). The methyl protons $\mathrm{H}-9 / \mathrm{H}-9^{\prime}$ showed $\mathrm{HMBC}$ correlations to $\mathrm{C}-3 / \mathrm{C}-3^{\prime}$ and $\mathrm{C}-4 / \mathrm{C}-4^{\prime}$, as well as illustrated COSY long-range correlation coupling to olefinic methine proton at $\mathrm{H}-4 / \mathrm{H}-4^{\prime}$, which confirmed the methyl substitution at C-3/C- $3^{\prime}$. The position of the hydroxy groups at C-8/C- $8^{\prime}$ was assigned by $\mathrm{HMBC}$ correlations from the proton signal at $\delta 11.56$ to the aromatic carbons at C-7/C-7', C-8/C-8' and C-8a/C-8a'. HMBC correlation from the methoxy proton signal at $\mathrm{H}-10 / \mathrm{H}-10^{\prime}$ to the aromatic carbon at $\delta$ 133.6 defined the substitution of methoxy groups at C-7/C-7'.

The framework of isocoumarin ring system and its connection to the other moiety were determined by HMBC NMR spectral data and 
<smiles>COc1c(O)c(-c2c(O)c(OC)c(O)c3c(=O)oc(C)c(O)c23)c2c(O)c(C)oc(=O)c2c1O</smiles>

1<smiles>CCC(C)=CCc1nc(OC)c(OC)c(O)c1C</smiles>

$\mathrm{MeO}$<smiles>COCCOC(=O)c1cccc2oc(-c3cccc4oc(-c5ccccc5O)nc34)nc12</smiles>

4<smiles>C[C@@H]1OC(=O)[C@H](Cc2ccccc2)[C@@H]1O</smiles>

6<smiles>COc1c(O)cc2cc(C)oc(=O)c2c1O</smiles>

2

3<smiles>COc1cc2cc(C)oc(=O)c2c(O)c1OC</smiles><smiles>C=CC(C)=C[C@@H](C)[C@@H](O)C(C)=CC</smiles>

Figure 1 The structures of secondary metabolites from Streptomyces sp. BCC 24731.

the comparison of ${ }^{13} \mathrm{C}$ NMR data with its monomer counterpart, reticulol (2). ${ }^{13} \mathrm{C}$ NMR spectroscopic data of 1 was discovered to be very similar to the corresponding data of 2 . The only difference was that each proton signal at $\mathrm{H}-5 / \mathrm{H}-5^{\prime}$ had disappeared and was, instead, replaced with the aromatic quaternary carbon signals at $\delta 107.3$ (C-5/ C- $\left.5^{\prime}\right)$. HMBC correlations from the aromatic methine proton signals $\mathrm{H}-4 / \mathrm{H}-4^{\prime}$ to the carbons $\mathrm{C}-5 / \mathrm{C}-5^{\prime}$ defined the substitution pattern of the carbon-carbon linkage at the position C-5/C- $5^{\prime}$. Thus, the structure of $\mathbf{1}$ can be established as $6,6^{\prime}, 8,8^{\prime}$-tetrahydroxy-7, $7^{\prime}$-dimethoxy-3,3'-dimethyl- 5,5'-biisocoumarin.

For the confirmation of the structure, the semi-synthetic reaction has been used to construct $\mathbf{1}$ via an intermolecular oxidative coupling reaction. Treatment of 2 with Iron (III) chloride $\left(\mathrm{FeCl}_{3}\right)$ was carried out under the condition that utilized meta-chloroperbenzoic acid ( $m$-CPBA) as the oxidant and dry $\mathrm{CH}_{2} \mathrm{Cl}_{2}$ as its solvent system ${ }^{20}$ (Figure 3). The product of 1 was obtained in $14 \%$ yield. The spectroscopic data of semi-synthetic $\mathbf{1}$ were identical in all respect to the naturally occurring compound.

As $\mathbf{1}$ is a symmetrical dimer of $\mathbf{2}$ with carbon-carbon bond that was characterized as a $5-5^{\prime}$ dimer, given that a large amount of $\mathbf{2}$ have also been obtained from the same Streptomyces, there was a possibility that 1 might be formed as artifact during the isolation process. Rapid extraction method of crude actinomycete followed by the analysis using HPLC was carried out. The result illustrated the presence of $\mathbf{1}$ in the crude extract, suggesting that $\mathbf{1}$ was produced by the microorganism and not an artifact.
Table $1{ }^{1} \mathrm{H},{ }^{13} \mathrm{C}$, COSY, NOESY and HMBC NMR Spectroscopic Data $\left(500 \mathrm{MHz}\right.$, acetone- $d_{6}$ ) for bireticulol

\begin{tabular}{|c|c|c|c|c|c|c|}
\hline C no. & $\delta_{C}$ & & $\delta_{H}$ & $\cos Y$ & $H M B C$ & NOESY \\
\hline $1,1^{\prime}$ & 166.8 & C & & & & \\
\hline $3,3^{\prime}$ & 153.4 & C & & & & \\
\hline $4,4^{\prime}$ & 102.2 & $\mathrm{CH}$ & $5.92 \mathrm{~s}$ & 9 & C-3, C-5, C-8a, C-9 & 9 \\
\hline $4 a, 4 a^{\prime}$ & 134.3 & $\mathrm{C}$ & & & & \\
\hline $5,5^{\prime}$ & 107.3 & C & & & & \\
\hline $6,6^{\prime}$ & 156.8 & C & & & & \\
\hline $7,7^{\prime}$ & 133.6 & C & & & & \\
\hline $8,8^{\prime}$ & 154.5 & $\mathrm{C}$ & & & & \\
\hline $8 a, 8 a^{\prime}$ & 99.4 & $\mathrm{C}$ & & & & \\
\hline $9,9^{\prime}$ & 18.3 & $\mathrm{CH}_{3}$ & $2.13 \mathrm{~s}$ & 4 & C-3, C-4 & 4 \\
\hline $10,10^{\prime}$ & 60.0 & $\mathrm{CH}_{3}$ & $3.91 \mathrm{~s}$ & & C-7 & \\
\hline $8-\mathrm{OH}, 8^{\prime}-\mathrm{OH}$ & & & $11.56 \mathrm{~s}$ & & C-7, C-8, C-8a & \\
\hline
\end{tabular}

Bireticulol (1) and compounds 2-6 were evaluated for cytotoxicity against MCF-7 (human breast cancer), KB (human epidermoid carcinoma), NCI-H187 (human small cell lung cancer), Vero cell lines and antimalarial activity against Plasmodium falciparum K1 strain (multi-drug resistant strain). These compounds were also tested for antibacterial activities against $S$. aureus, B. cereus and E. coli. In addition, they were further investigated for anti-TB, antifungal activities against $C$. albicans and plant pathogen M. grisea. Results showed that none of the obtained metabolites were active in the anti$\mathrm{TB}$, anti-M. grisea or the antibacterial assays. As for antimalarial and antifungal activities, only piericidin A (4) exhibited inhibition against Plasmodium falciparum $\mathrm{K} 1$ at $\mathrm{IC}_{50}$ of $3.45 \mu \mathrm{g} \mathrm{ml}^{-1}$ and inhibited C. albicans with MIC value of $5.33 \mu \mathrm{g} \mathrm{ml}^{-1}$. All of the tested compounds were also reported to be non-cytotoxic against Vero cells. Biological activities against different cancer cell lines including MCF-7, KB and NCI-H187 were determined and results are illustrated in Table 2.

The newly derived $\mathbf{1}$ along with other known isocoumarins and polyketides are reported in this study to express moderate to weak cytotoxic activities against MCF-7, KB and NCI-H187 cell lines. Bireticulol exhibited cytotoxicity against $\mathrm{KB}$ cell lines with $\mathrm{IC}_{50}$ values of $24.4 \mu \mathrm{g} \mathrm{ml}^{-1}$, while expressed inhibition against NCI-H187 cell lines at $\mathrm{IC}_{50}$ of $8.31 \mu \mathrm{g} \mathrm{ml}^{-1}$. Interestingly, 2 showed no inhibition against all three cancer cell lines. The presence of dimeric skeleton apparently increased inhibitory activities of $\mathbf{1}$ in these anti-cancer assays. In addition, comparison of cytotoxic activities between $\mathbf{2}$ and its closely related derivative $\mathbf{3}$ also illustrated a similar trend. The presence of a methoxy group instead of a hydroxyl at position C- 6 in $\mathbf{3}$ seemed to have effect on its biological activities, as 3 also exhibited inhibition against all the three cancer cell lines, whereas 2 expressed none. For other known isolated metabolites, which are not isocoumarin related, 4 and 5 showed moderate to weak bioactivities against all the three cancer cell lines, whereas $\mathbf{6}$ was inactive against all of them.

\section{EXPERIMENTAL PROCEDURE}

\section{General}

UV spectrum was obtained using a GBC Cintra 404 UV-visible spectrophotometer (GBC Scientific Equipment, Victoria, Australia). FT-IR spectrum was recorded on a Bruker VECTOR 22 spectrometer (Bruker Optik GmbH, Ettlingen, Germany). ${ }^{1} \mathrm{H},{ }^{13} \mathrm{C}$, DEPT, COSY, HMQC, HMBC and NOESY NMR spectra were recorded on a Bruker AV500D spectrometer (Bruker, Switzerland). High resolution ESITOF mass spectrum was measured with a 


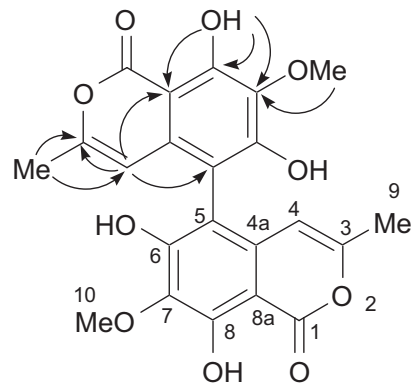

Figure 2 Selected HMBC (arrows) correlations observed in the NMR spectra for bireticulol.

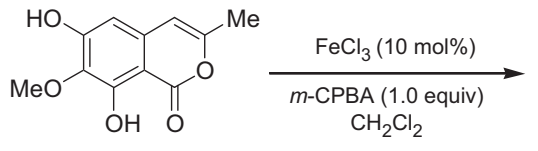<smiles>COc1cc(-c2c(O)c(O)c(OC)c3c(O)c(OC)c(=O)oc23)c2cc(C)oc(=O)c2c1O</smiles>

Figure 3 Semi-synthesis of bireticulol by oxidative coupling reaction.

Bruker micrOTOF mass spectrometer (Bruker Daltonik GmbH, Bremen, Germany) in positive mode.

\section{Biological material}

Streptomyces sp. (BCC 24731/A-T 0762) was isolated from the soil under bamboo trees collected at evergreen forest, Khuean Srinagarindra National Park, Kanchanaburi, Thailand. The collection and taxonomic identification were performed by Chanwit Suriyachadkun (BIOTEC). This actinomycete strain was previously identified as Streptoverticillium sp. A specimen has been deposited at BIOTEC Culture Collection (BCC) and registered as BCC 24731.

\section{Culture condition}

Streptomyces BCC 24731 was maintained on ISP2 (International Streptomyces Project 2) medium at $28{ }^{\circ} \mathrm{C}$ for 21 days. The agar plate culture was chopped into pieces $\left(1 \times 1 \mathrm{~cm}^{2}\right)$ and transferred to $250 \mathrm{ml}$ Erlenmeyer flasks, containing $25 \mathrm{ml}$ of Bio 19 liquid medium at $\mathrm{pH}$ 7. The Bio 19 medium consisted of (w/v): glucose, $2 \%$; peptone, $0.5 \%$; yeast extract, $0.3 \%$; meat extract, $0.5 \%$; $\mathrm{NaCl}$, $0.05 \% ; \mathrm{CaCO}_{3}, 0.3 \%$. The seed culture was incubated at $28^{\circ} \mathrm{C}$ on a rotary shaker ( 250 r.p.m.) for 7 days. Later, the seed culture was inoculated into $1000 \mathrm{ml}$ Erlenmeyer flasks containing $250 \mathrm{ml}$ of Bio 19 liquid medium, and incubated at $28^{\circ} \mathrm{C}$ on a rotary shaker (250 r.p.m.) for 7 days.

\section{Large-scale fermentation}

Approximately $600 \mathrm{ml}$ of seed culture was inoculated into 101 fermentor vessel (BMT, B.E. Marubishi, Thailand) containing 61 of production medium LS2 ( $\mathrm{pH}$ 6.2), which composed of $(\mathrm{w} / \mathrm{v})$ : manitol, $2 \%$; soy meal, $2 \%$; $(\mathrm{v} / \mathrm{v})$ trace elements, $0.025 \%$. The mixture of trace elements consisted of (w/v): $\mathrm{CaCl}_{2}$, $0.4 \% ; \mathrm{ZnSO}_{4}, 0.2 \% ; \mathrm{Na}_{2} \mathrm{~B}_{4} \mathrm{O}_{7}, 0.01 \% ; \mathrm{FeSO}_{4}, 0.5 \% ; \mathrm{KI}, 0.005 \% ; \mathrm{CoCl}_{2}, 0.05 \%$; $\mathrm{CuSO}_{4}, 0.02 \% ; \mathrm{MnCl}_{2}, 0.2 \% ; \mathrm{Na}_{2} \mathrm{MoO}_{4}, 0.005 \%$; (v/v) $\mathrm{H}_{2} \mathrm{SO}_{4}$ (95-97\% p.a.), $0.1 \%$. The temperature was set at $28{ }^{\circ} \mathrm{C}$. The aeration and agitation rates were 0.1 v.v.m. and 250 r.p.m. The fermentation of cultures was carried out for 7 days.

\section{Extraction and isolation}

After 7 days, the organic constituents from a 61 culture of Streptomyces sp. strain BCC24731 were extracted by a solid-phase extraction method using Amberlite XAD-7 resin (Supelco, Bellefonte, PA, USA). Amberlite XAD-7 resin $\left(20 \mathrm{gl}^{-1}\right)$ was added to 61 of culture to adsorb the organic substances. The
Table 2 Cytotoxic Activities against various cancer cell lines of 1-6

\begin{tabular}{lccc}
\hline Compound & $\begin{array}{c}\text { MCF-7 inhibition } \\
I C_{50}\left(\mu g \mathrm{~m}^{-1}\right)\end{array}$ & $\begin{array}{c}\text { KB inhibition } \\
\left.I_{50}(\mu \mathrm{g} \mathrm{m})^{-1}\right)\end{array}$ & $\begin{array}{c}\text { NCl-H187 inhibition } \\
I C_{50}\left(\mu g \mathrm{~m}^{-1}\right)\end{array}$ \\
\hline $\mathbf{1}$ & Not tested & 24.4 & 8.31 \\
$\mathbf{2}$ & Inactive & Inactive & Inactive \\
$\mathbf{3}$ & 26.1 & 21.4 & 19.8 \\
$\mathbf{4}$ & 26.1 & 40.5 & 5.72 \\
$\mathbf{5}$ & 26.9 & 21.7 & 8.02 \\
$\mathbf{6}$ & Inactive & Inactive & Inactive \\
\hline
\end{tabular}

Abbreviations: 1, bireticulol; 2, reticulol; 3, 8-hydroxy-6,7-dimethoxy-3-methyl isocoumarin; 4, piericidin A; 5, UK-1; 6, 3-benzyl-4-hydroxy-5-methyldihydrofuran-2-one. $\mathrm{IC}_{50}>50 \mu \mathrm{g} \mathrm{ml}^{-1}$ was inactive.

culture and resin were shaken at 200 r.p.m. overnight and subsequently filtered through cheesecloth and washed with deionized water. The resin and the cheesecloth were submerged in acetone and shaken at 200 r.p.m. for $3 \mathrm{~h}$ to elute out all substances. The crude acetone extract was dried in vacuo to yield a dark brown substance $(10.9 \mathrm{~g}$ ), which was partitioned by Diaion HP20SS (Supelco, Bellefonte, PA, USA) column chromatography $(3.5 \times 25 \mathrm{~cm}$, acetone:water) to yield nine fractions $(20,30,40,50,60,70,80,90$ and $100 \%$ acetone mixtures). Crystals were found to establish in 60 and $70 \%$ fractions, and could be later identified as $2(362.8 \mathrm{mg})$. The fraction eluted with $100 \%$ acetone was found to contain white precipitated solid, which after crystalization from chloroform/ methanol mixtures $(80 / 20)$, gave the pure compound $5(33 \mathrm{mg})$.

After the removal of crystals, all other fractions were concentrated to dryness and evaluated using NMR profiles. The fraction which eluted with $60 \%$ acetonewater $(280 \mathrm{mg})$ was subjected to further purification by gradient preparative HPLC using a reversed-phase column (Phenomenex Luna $10 \mu \mathrm{C} 18$ (2) 100A, $21.2 \times 250 \mathrm{~mm}, 10 \mu \mathrm{m}$ (Phenomenex LUNA, Torrance, CA, USA); $10 \mathrm{ml} \mathrm{min}^{-1}$, $30 \% \mathrm{MeCN} / \mathrm{H}_{2} \mathrm{O}$ over $10 \mathrm{~min}, 30-35 \% \mathrm{MeCN} / \mathrm{H}_{2} \mathrm{O}$ over $5 \mathrm{~min}, 35-40 \%$ $\mathrm{MeCN} / \mathrm{H}_{2} \mathrm{O}$ over $\left.25 \mathrm{~min}\right)$ to give $6(13.9 \mathrm{mg})$. The $70 \%$ acetone-water fraction $(383 \mathrm{mg}$ ) was also subjected to the purification by gradient HPLC (Phenomenex Luna $\mathrm{C}_{18}$ preparative, $10 \mathrm{ml} \mathrm{min}^{-1}, 20-100 \% \mathrm{MeCN} / \mathrm{H}_{2} \mathrm{O}$ over $\left.60 \mathrm{~min}\right)$ to afford 1 (7.4 mg), $2(239.9 \mathrm{mg})$ and $3(12.7 \mathrm{mg})$. The $80 \%(418 \mathrm{mg})$ and $90 \%$ $(510 \mathrm{mg})$ acetone-water fractions were further purified by gradient HPLC (Phenomenex Luna $\mathrm{C}_{18}$ preparative, $10 \mathrm{ml} \mathrm{min}^{-1}, 20-100 \% \mathrm{MeCN} / \mathrm{H}_{2} \mathrm{O}$ over $40 \mathrm{~min})$ to yield $1(9.3 \mathrm{mg}), 2(17 \mathrm{mg})$, and $4(199 \mathrm{mg})$.

\section{Bireticulol (1)}

Yellow amorphous powder; UV (MeOH) $\lambda_{\max }(\log \varepsilon) 243 \mathrm{~nm}(3.74), 331 \mathrm{~nm}$ (4.50); IR $v_{\max }(\mathrm{KBr}) 3449,1679,1640,1467,1385,1347,1089 \mathrm{~cm}^{-1}$; NMR data, see Table 1; ESIMS $[\mathrm{M}+\mathrm{H}]^{+} \mathrm{m} / z$ 443; ESIMS $[\mathrm{M}-\mathrm{H}]^{-} \mathrm{m} / \mathrm{z}$ 441; HRESITOFMS $[\mathrm{M}+\mathrm{Na}]^{+} \mathrm{m} / \mathrm{z} 465.0803$ (calcd for $\mathrm{C}_{22} \mathrm{H}_{18} \mathrm{O}_{10} \mathrm{Na}, 465.0798$ ), HRESITOFMS $[\mathrm{M}+\mathrm{H}]^{+} \mathrm{m} / \mathrm{z} 443.0986$ (calcd for $\mathrm{C}_{22} \mathrm{H}_{19} \mathrm{O}_{10}, 443.0978$ ).

\section{Preparation of bireticulol by oxidative coupling reaction} Anhydrous $\mathrm{FeCl}_{3}(0.4 \mathrm{mg}, 0.003 \mathrm{mmol})$ and $m$-CPBA $(4.3 \mathrm{mg}, 0.025 \mathrm{mmol})$ were added to a solution of $2(2,5.1 \mathrm{mg}, 0.023 \mathrm{mmol})$ in dry $\mathrm{CH}_{2} \mathrm{Cl}_{2}(5 \mathrm{ml})$. The reaction solution was stirred at room temperature overnight then quenched with $\mathrm{H}_{2} \mathrm{O}(5 \mathrm{ml})$. The aqueous phase was extracted with $\mathrm{CH}_{2} \mathrm{Cl}_{2}$ and the combined organic phase was evaporated in vacuo to yield the lightyellow substance. The crude material from the reaction was further purified by gradient HPLC (Phenomenex Luna $\mathrm{C}_{18}$ preparative, $10 \mathrm{ml} \mathrm{min}^{-1}, 20-100 \%$ $\mathrm{MeCN} / \mathrm{H}_{2} \mathrm{O}$ over $\left.60 \mathrm{~min}\right)$ to afford bireticulol $(1,0.7 \mathrm{mg})$.

\section{Biological assays}

Cytotoxicity against Vero cell (African green monkey kidney fibroblasts, ATCC CCL-81) was determined using the green fluorescent protein (GFP)-based assay, ${ }^{21}$ whereas cytotoxic tests against cancer cell lines, including $\mathrm{KB}$ (human epidermoid carcinoma, ATCC CCL-17), MCF-7 (human breast cancer, ATCC HTB-22), and NCI-H187 (human small cell lung cancer, ATCC CRL-5804) were performed using the resazurin microplate assay (REMA). ${ }^{22}$ Antimalarial activity against Plasmodium falciparum $\mathrm{K} 1$ was tested by the microculture radio isotope technique. ${ }^{23}$ Antimicrobial assays were also carried out using the resazurin 
microplate technique. ${ }^{24}$ Anti-mycobacterium tuberculosis ( $\mathrm{H}_{37} \mathrm{Ra}$ strain) assay was performed using GFP microplate assay (GFPMA) ${ }^{25}$ Anti-rice blast disease pathogen (Magnaporthe grisea) assay was carried out by using the method of 5,(6)-carboxy fluorescene diacetate (CFDA) fluorometric detection. ${ }^{26}$

\section{ACKNOWLEDGEMENTS}

We are grateful to Bioresources Research Network (BRN) of the National Center for Genetic Engineering and Biotechnology (BIOTEC) for financial support.

1 Hill, R. A. Naturally occurring isocoumarins. Fortschr. Chem. Org. Nat.Stoffe. 49, 1-78 (1986).

2 Whyte, A. C., Gloer, J. B., Scott, J. A. \& Mallock, D. Cercophorins AC: novel antifungal and cytotoxic metabolites from the coprophilous fungus Cercophora areolata. J. Nat. Prod. 59, 765-769 (1996).

3 Hussain, M. T., Rama, N. H. \& Malik, A. Synthesis of some new 3-(bromophenyl)isocoumarins and their conversion to (dl)-3,4-dihydroisocoumarins. Indian J. Chem., Sect. B. 40, 372-376 (2001).

4 Cañedo, L. M. et al. PM-94128, a new isocoumarin antitumor agent produced by a marine bacterium. J. Antibiot. 50, 175-176 (1997).

5 Furuta, T., Fukuyama, Y. \& Asakawa, Y. Polygonolide, an isocoumarin from Polygonum hydropiper possessing anti-inflammatory activity. Phytochemistry 25, 517-520 (1986).

6 Matsuda, H., Shimoda, H. \& Yoshikawa, M. Structure-Requirements of isocoumarins, phthalides, and stilbenes from hydrangeae dulcis folium for inhibitory activity on histamine release from rat peritoneal mast cells. Bioorg. Med. Chem. Lett. 7, 1445-1450 (1999).

7 Chinworrungsee, M. et al. Halorosellins $A$ and $B$, unique isocoumarin glucosides from the marine fungus Halorosellinia oceanica. J. Chem. Soc., Perkin Trans. 1, 2473-2476 (2002).

8 Devienne, K. F. et al. Antioxidant activity of isocoumarins isolated from Paepalanthus bromelioides on mitochondria. Phytochemistry 68, 1075-1080 (2007).

9 Snyder, J. et al. The structure of castanaguyone a biisocoumarin plant product. Tetrahedron Lett. 22, 5015-5018 (1981).

10 Yemele Bouberte, M. et al. Tithoniamarin and tithoniamide: a structurally unique isocoumarin dimer and a new ceramide from Tithonia diversifolia. Nat. Prod. Res. 20, 842-849 (2006).
11 Mitscher, L. A., Andres, W. W. \& McCrae, W. Reticulol, a new metabolic isocoumarin. Experientia. 20, 258-259 (1964).

12 Lin, J., Yoshida, S. \& Takahashi, N. Metabolites produced by Streptomyces mobaraensis. Agr. Biol. Chem. 35, 363-369 (1971).

13 Eaton, M. A. W. \& Hutchinson, D. W. Isocoumarins from Streptomyces mobaraensis. Tetrahedron Lett. 18, 1337-1340 (1971).

14 Tamura, S. et al. Isolation and physiological activities of piericidin A, a natural insecticide produced by Streptomyces. Agr. Biol. Chem. 27, 576-582 (1963).

15 Takahashi, N., Suzuki, A. \& Tamura, S. Structure of piericidin A. J. Am. Chem. Soc. 87, 2066-2068 (1965)

16 Ueki, M. et al. UK-1, a Novel Cytotoxic Metabolite from Streptomyces Sp 517-02. I: Taxonomy, Fermentation, Isolation, Physicochemical and Biological Properties. J. Antibiot. 46, 1089-1094 (1993).

17 Shibata, K., Kashiwada, M., Ueki, M. \& Taniguchi, M. UK-1, a Novel Cytotoxic Metabolite from Streptomyces Sp 517-02. II. Structural Elucidation. J. Antibiot. 46, 1095-1100 (1993).

18 Hanafi, M., Shibata, K., Ueki, M. \& Taniguchi, M. UK-2A, B, C and D, novel antifungal antibiotics from Streptomyces sp. 517-02. II. Structural elucidation. J. Antibiot. 49, 1226-1231 (1996).

19 Shimano, M. et al. Total synthesis of the antifungal dilactones UK-2A and UK-3A: The determination of their relative and absolute configurations, analog synthesis and antifungal activities. Tetrahedron 54, 12745-12774 (1998).

20 Wang, K., Lü, M., Yu, A., Zhu, X. \& Wang, Q. Iron(III) chloride catalyzed oxidative coupling of aromatic nuclei. J. Org. Chem. 74, 935-938 (2009).

21 Changsen, C., Franzblau, S. G. \& Palittapongarnpim, P. Improved green fluorescent protein reporter gene-based microplate screening for antituberculosis compounds by utilizing an acetamidase promoter. Antimicrob. Agents Chemother. 47, 3682-3687 (2003).

22 O'Brien, J., Wilson, I., Orton, T. \& Pognan, F. Investigation of the Alamar Blue (resazurin) fluorescent dye for the assessment of mammalian cell cytotoxicity. Eur. J. Biochem. 267, 5421-5426 (2000).

23 Desjardins, R. E., Canfield, C. J., Haynes, J. D. \& Chulay, J. D. Quantitative assessment of antimalarial activity in vitro by a semiautomated microdilution technique. Antimicrob. Agents Chemother. 16, 710-718 (1979).

24 Sarker, S. D., Nahar, L. \& Kumarasamy, Y. Microtitre plate-based antibacterial assay incorporating resazurin as an indicator of cell growth, and its application in the in vitro antibacterial screening of phytochemicals. Methods. 42, 321-324 (2007).

25 Collins, L. A., Torrero, M. N. \& Franzblau, S. G. Green fluorescent protein reporter microplate assay for high-throughput screening of compounds against Mycobacterium tuberculosis. Antimicrob. Agents Chemother. 42, 344-347 (1998).

26 Haugland, R. P. in Handbook of Fluorescent Probes and Research Products, 9th edn (ed. Gregory, J.) 996 (Molecular Probes, Inc., Eugene, Oregon, 2002).

Supplementary Information accompanies the paper on The Journal of Antibiotics website (http://www.nature.com/ja) 